\title{
色素性皮膚病変以外の疾患に対する ダーモスコピーの活用法
}

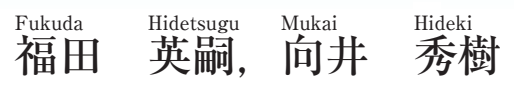

\begin{abstract}
要 旨
ダーモスコピーは診療の様々な場面で使用され, 特に悪性黒色腫や基底細胞癌, 色素性母斑, 脂漏性角化症などの色素性皮膚病変での有用性は確立している. 今回, 日常診療でしばしば遭 遇する色素性皮膚病変以外の疾患（疥癬や伝染性軟属腫, 尋常性病賛) での所見や, 尋常性病 贅の治療経過, 皮脂欠乏症に打ける乾燥症状の観察での活用法について報告した。疥癖は, 痂 皮などの直接鏡検にてヒゼンダニを確認した場合に確定診断出来るが,「疥癬診療ガイドライ ン」では, ダーモスコピーでヒゼンダニを確認した場合も疥痽と診断出来ると記載されている. 疥癬のダーモスコピー所見は, ヒゼンダニの虫体を反映する灰褐色三角形構造 (gray delta structures), 疥㿈トンネルを反映する飛行機雲様所見 (jet with contrail), その他, 水尾所見 （wake）がある. 伝染性軟属腫は視診で診断可能な場合が多いが, 小型の病変やアトピー性皮 虐炎に合併するwhite fibrous papulosis of the neckでは時に診断に苦慮する。伝染性軟属腫の ダーモスコピー所見は, 内部は白色調で, 中央にリング状の鱗首があり, その周囲に毛細血管 拡張 (crown vessels) を認める. 尋常性病賛では, 小型の病変の確認や治療経過の観察時にダ ーモスコピーは有用であり, 肉眼で判別困難な角化やdotted vesselsの有無を確認出来る. 皮脂 欠乏症患者では, 肉眼的に皮膚の乾燥を確認できれば保湿外用薬の外用を行うが, 確認できな い場合には外用の中断がしばしばみられる。 そのような患者の場合, ダーモスコピーは乾燥状 態の程度を診察時に示すことができるため, 保湿外用薬の外用アドヒアランスを高める一つの ッールとしても有用である。
\end{abstract}

Key words : ダーモスコピー(dermoscopy), 疥癬 (scabies), 伝染性軟属腫 (molluscum contagiosum), 尋常性疮贅 (verruca vulgaris), 皮脂欠乏症 (asteatosis)

\section{はじめに}

ダーモスコピーは診療の様々な場面で使用され,

\section{福田 英嗣 Fukuda Hidetsugu}

向井 秀樹 Mukai Hideki

東邦大学医療センター大橋病院皮膚科学教室

別刷請求先：福田 英嗣

東邦大学医療センター大橋病院皮膚科学教室

干153-8515 東京都目黒区大橋2-17-6
悪性黒色腫や基底細胞癌, 色素性母斑, 脂漏性角 化症などの色素性皮膚病変での有用性は確立して いる。 今回, 日常診療でしばしば遭遇する色素性 皮膚病変以外の疾患（疥痽や伝染性軟属腫, 尋常 性病贅）における所見や, 尋常性病贅の治療経過, 皮脂欠乏症の乾燥症状や治療経過の観察時におけ るダーモスコピーの活用法について報告した。 


\section{使用するダーモスコピーの種類}

ダーモスコピーには接触型機器と非接触型機器 があり，接触型ではmilia-like cystsやcomedo-like openingsなどが観察されやすく，偏光を用いる非 接触型は血管所見などが観察されやすい. 当科で は, 接触型機器としてHAINE DELTA $10^{\circledR}$ やBIO CAM Dermo Genius ${ }^{\circledR}$, 非接触型機器としてエピ ライトエイト ${ }^{\circledR}$ を使用している.

\section{疥 癬}

ヒゼンダニがヒトの皮膚の角層に寄生して生じ る皮膚感染症で, 性行為感染症 (Sexually Transmi tted Diseases : STD)の一つである. 近年ではSTD として発症する場合は少なく，新患患者のほとん どが高齢者施設を中心に発症した高齢者と, その 介護者である。ヒゼンダニの成熟䧳成虫の体長は

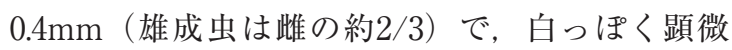
鏡下では円板状で, 肉眼で見つけることは困難で ある．確定診断には泇皮などの検体を直接鏡検し， ヒゼンダニの虫体や虫卵を確認する必要があるが, 「疥痛診療ガイドライン」ではダーモスコピーで ヒゼンダニを確認した場合も疥净と診断可能と記 載されている1).

ダーモスコピー所見は，(1)灰褐色三角形構造： gray delta structures 化ゼンダニの虫体を反映: ヒゼンダニの頭部と前脚が色素を帯びているため 生じる（図1）\}，(2)飛行機雲様所見：jet with

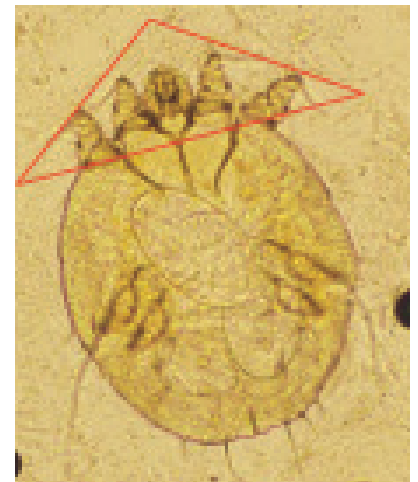

図 1 疥癬虫体の直接鏡検所見 contrail（疥痽トンネルを反映), (3)水尾所見： wakeがある ${ }^{2)}$ (図 2 )。灰褐色三角形構造より検 体を採取すると，ヒゼンダニの虫体の検出が比較 的容易となる.

[症例］49歳, 男性. 陰囊および陰茎の棒みを伴う 結節を主訴に当科を受診した。受診時，体幹に皮 疹はなく, 除囊および陰茎に結節があり, 左第 4 指間に 1 力所線状に盛り上がる病変を認めた（図 $3,4)$. 指間部のダーモスコピー所見にて，灰褐

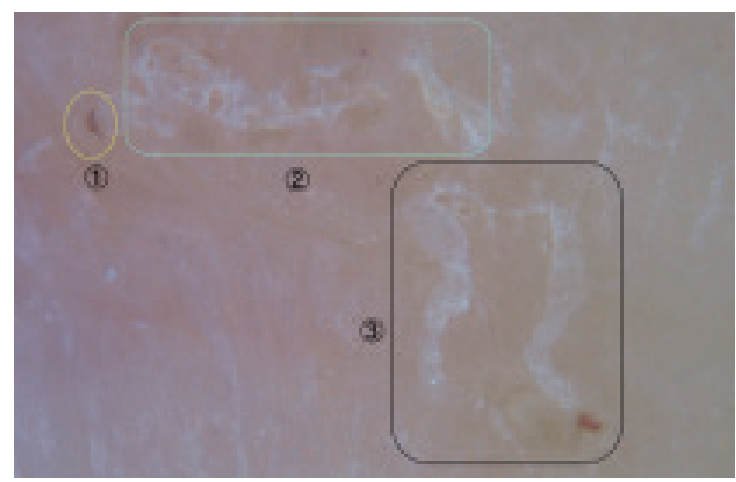

図2 疥癬のダーモスコピー所見

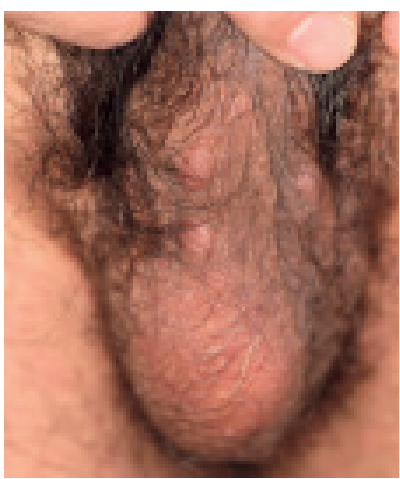

図 3 疥癬の臨床所見（陰囊の結節）

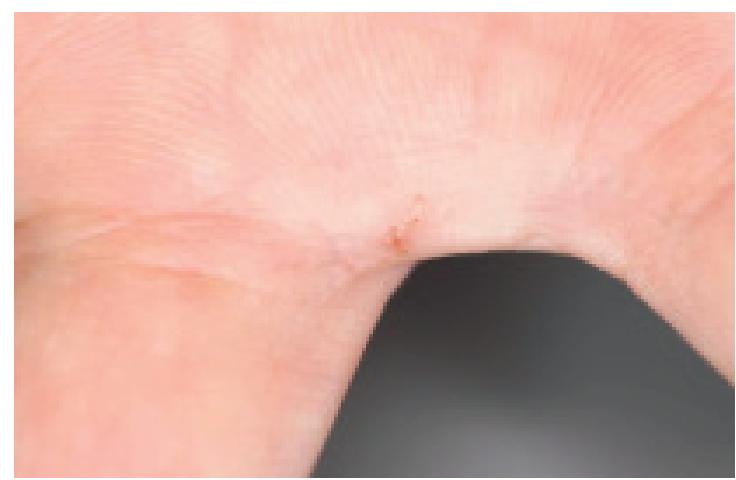

図 4 疥癬の臨床所見（指間の疥癬トンネル） 
色三角形構造と飛行機雲様所見を認めた（図 5 ). 同部位から採取した検体の直接鏡検にて, ヒゼン ダニの虫体と虫卵を確認した（図 5$)$ ，以上より， 自験例を痰鹰と診断した。

臨床的に疥癄を疑った場合は, ダーモスコピー を用いることでヒゼンダニの虫体や虫卵の検出が より確実になるため, 診断率の向上に繋がる.さ らに, 必要以上の検体採取が不要となることから， 検体採取時の疼痛軽減となる。

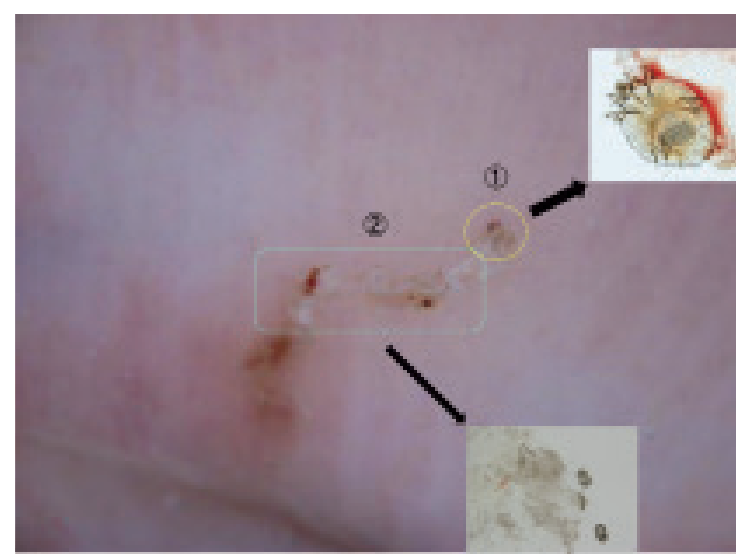

図 5 疥癬のダーモスコピー所見と直接鏡検所見

\section{伝染性軟属腫}

ポックスウイルスに属する伝染性軟属腫ウイル スによる感染症である。小児の体幹や四肢に好発 する数mm大までの常色や白色, 淡紅色の小結節 で, 半球状に隆起し, 中央は臍窩状に陥凹する（図 6 ).

ダーモスコピー所見は，(1)全体的に白みを帯び た淡紅色調, (2)中央部分の白色リング状構造, (3) 白色リング状構造周囲の毛細血管拡張 (crown vessels）がある（図 7 )。病理組織所見は, 表皮 が真皮方向へ囊腫状に増殖・肥厚し, 病変の中央 部は陥凹し，陥凹部の表皮は過角化を伴っている。 表皮内には多数の卵円形で好酸性の封入体 （molluscum body）を持つ角化細胞が見られる ${ }^{3)}$. 真皮上層では毛細血管の拡張を認める（図８）.
これらの所見は, 表皮肥厚とmolluscum bodyが 結節の全体的な白色調部分, 過角化が結節中央の 白色リング状構造, 真皮上層の毛細血管の拡張が 白色リング状構造周囲の毛細血管拡張（crown vessels）に対応する。

[症例］ 3 歳, 女肾. 右肩部の白色小結節を主訴 に当科を受診した，受診時，右肩に $0.5 \mathrm{~mm}$ 大まで の白色小結節が散在していた（図6)。白色小結 節のダーモスコピー所見では, 全体的に白みを带 びた淡紅色調で, 中央部分に白色リング状構造が あり，その周囲に毛細血管搪張 (crown vessels) を認めた（図 7 ). 以上より, 自験例を伝染性軟 属腫と診断した.

[鑑別] 伝染性軟属腫は, 小型の病変では光沢苔 痽, 大型の病変ではwhite fibrous papulosis of the

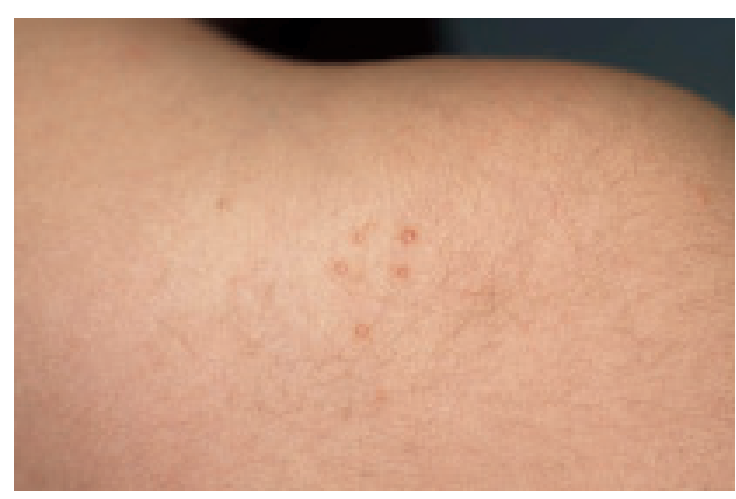

図 6 伝染性軟属腫の臨床所見（肩部の小結節）

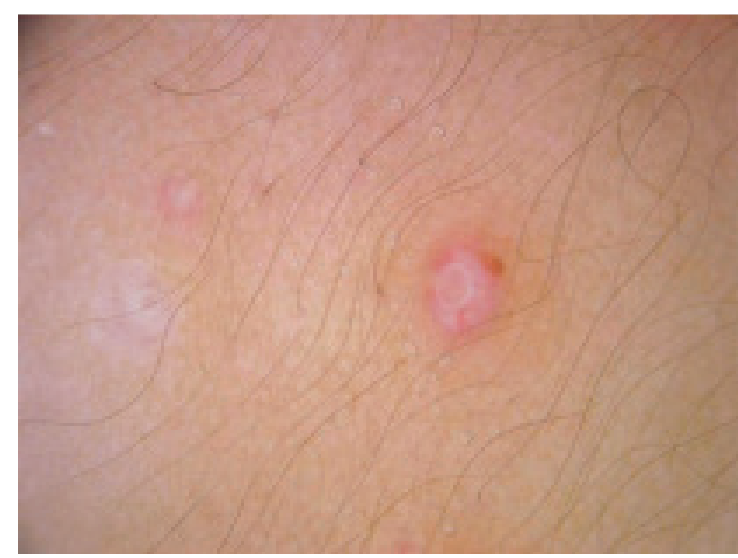

図7伝染性軟属腫のダーモスコピー所見 
neckなどと鑑別を要す. White fibrous papulosis of the neckは, 中高齢者の頸部に両側性に多発す る白色調の小結節である ${ }^{4)}$. ダーモスコピー所見 は, (1)毛孔に一致しない円形白色領域で, (2)内部 に微小な点状血管あり, (3)病変周辺に血管所見を 伴わないと記載されている5）6）アアトピー性皮膚 炎患者では, 同様の症状が頸部以外にもしばしば 観察され（図 9)，ステロイド外用薬の影響が示 唆されている7).

アトピー性皮膚炎患者では, しばしば伝染性軟 属腫も合併するため, 鑑別を要す。その際，中央 の白色リング状構造の有無は両者の鑑別に有用で ある.また,アトピー性皮膚炎患者でみられるwhite fibrous papulosis of the neck様皮疹では, crown vesselsも存在しないため鑑別可能である（図10）.

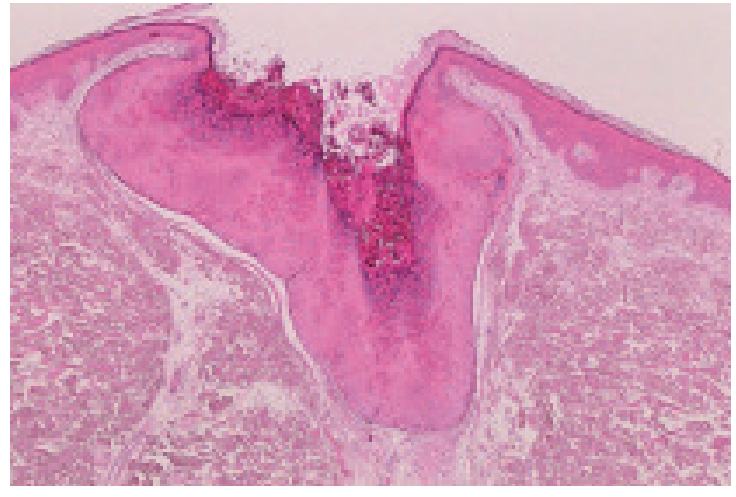

図 8 伝染性軟属腫の病理組織所見（HE染色）

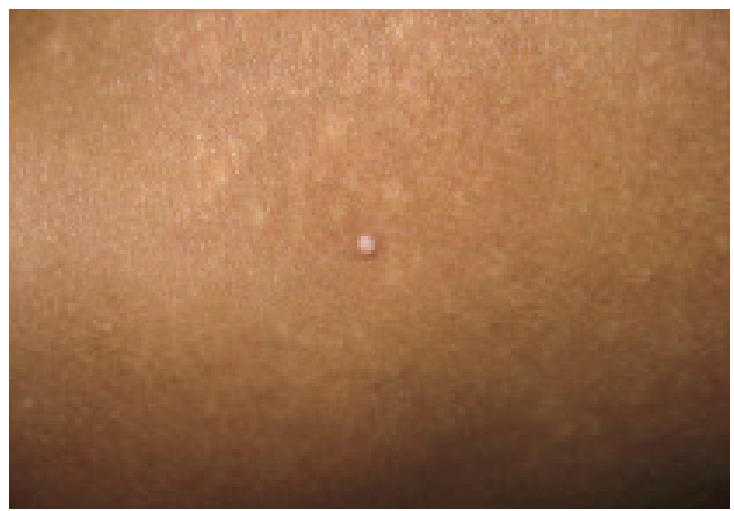

図 9 アトピー性皮膚炎患者にみられたwhite fibrous papulosis of the neck様皮疹

\section{尋常性疣贅}

パポバウイルス科のヒト乳頭腫ウイルスによる 感染症である. 指趾などの四肢末端に好発するが, 体のどの部位にも生じうる。肉眼的に診断可能な 場合が多いが，小型の病変では診断に苦慮する場 合がある。その際にダーモスコピーは有用である。 ダーモスコピー所見は，(1)過角化を伴う隆起性乳 頭状構造 : exophytic papillary structures with hyperkeratosis，(2)乳頭頂部を囲む白色角化性区 画，(3)乳頭頂部の点状〜ヘアピン血管ないし点状 出血塊 : dotted/hairpin vessels and/or small reddish black dots/clods in the tops of dermal papillae (図 11）がある ${ }^{8)}$ 。また，液体窒素などの治療経過を 観察する際にも有効である（図12）。

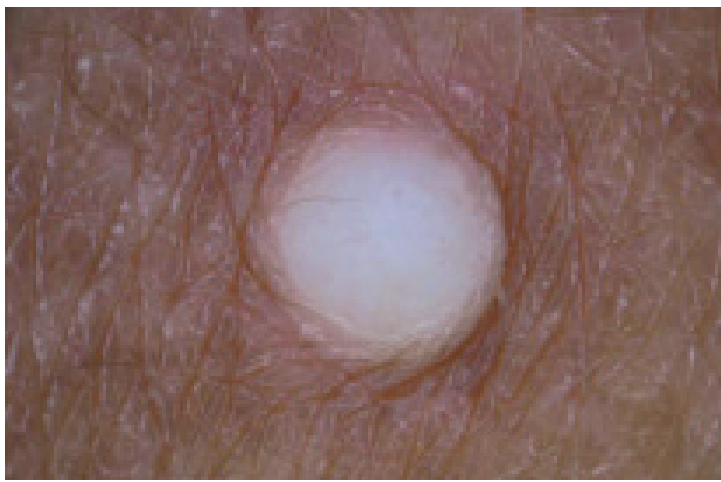

図10 White fibrous papulosis of the neck様 皮疹のダーモスコピー所見

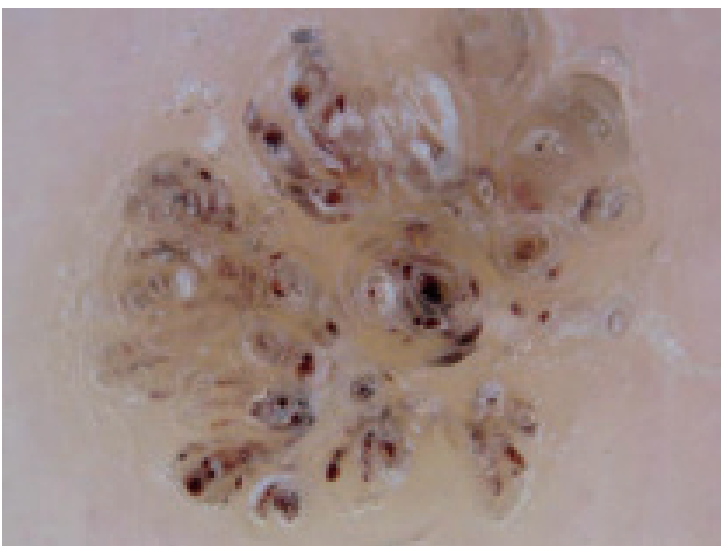

図11 尋常性疣贅のダーモスコピー所見 


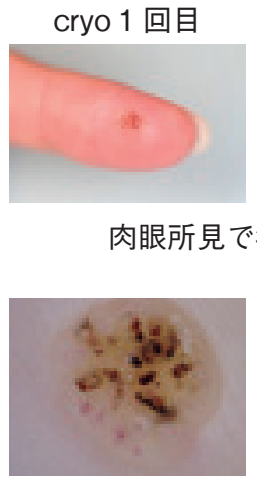

(1) (2) (3)

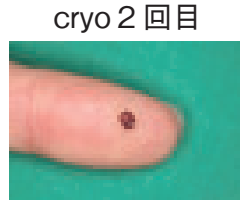

病変の残存あり

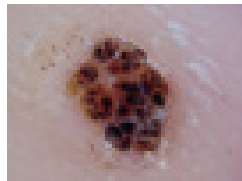

(1) (2) (3)
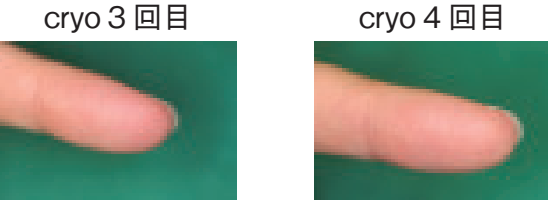

肉眼所見で病変の残存なし

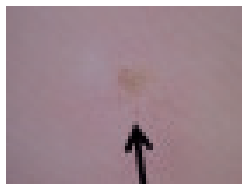

(3)

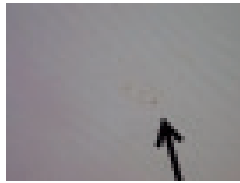

(3)

ダーモスコピー所見にて病変の残存あり (○内の数字は残存するダーモスコピー所見)
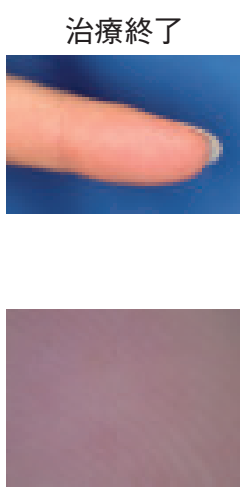

ダーモスコピー 所見にて病変の 残存なし

図12 尋常性疣贅の治療経過一臨床所見との比較一

図12のごとく，肉眼的に病変の残存がない場 合においても, ダーモスコピーでは点状の出血が 残存していることがあり, 治療経過を観察する際 には肉眼所見に加え, ダーモスコピー所見も加味 した治癒判定が望ましいと思われる。

\section{皮脂欠乏症}

皮脂の減少や角質水分量の低下などで皮膚が乾 燥した状態が皮脂欠そ症である。症状が顕在化す るのは, 大気が乾燥する秋から冬で, 下腿伸側に 好発する。初期症状としては, 肉眼的に鱗首など はなく皮膚の光沢を失っているのみの状態で, ダ
ーモスコピーの観察ではじめて鱗屑が観察される 程度であり（図13の初診時）, 徐々に肉眼的に観 察される乾燥, 粗造化, 粌糠様鱗屑が出現する. その後，掻破による掻破痕や痂皮，びらんが混在 し，皮脂欠乏性湿疹の病像が完成する。

皮脂欠乏症患者では，肉眼的に皮膚の乾燥を確 認できれば保湿外用薬の外用を行うが，確認でき ない場合には外用の中断がみられる。初診時や再 診時にダーモスコピーを用いて皮膚の乾燥状態を 示すことで, 乾燥の程度を確認でき, その後の外 用の継続に繋がる（図13）。このように，皮脂欠 そ症の患者においてダーモスコピーは，保湿外用
初診時
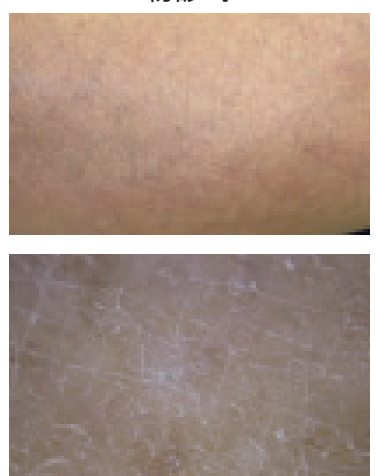

著明な乾燥
2 週間後
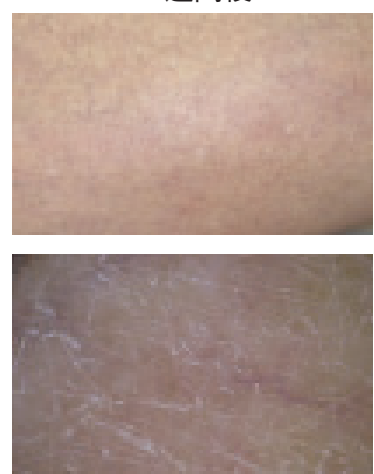

乾燥の軽減
1 力月後
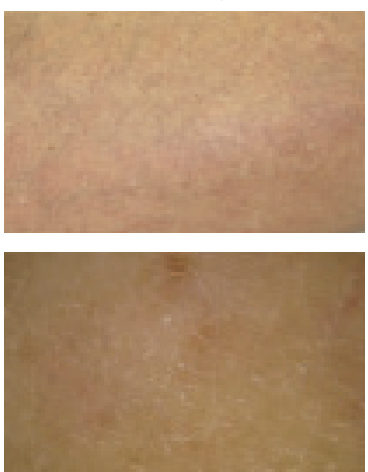

わずかに乾燥残存
2 力月後
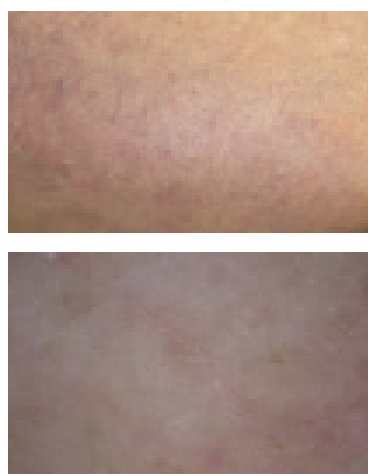

乾燥消失

図13 保湿外用薬の外用による経時的変化 
薬の外用アドヒアランスを向上する一つのツール として有用である.

\section{おわりに}

ダーモスコピーは，検査に要す時間が短時間で あり，積極的に日常診療に取り入れることで診断 や治療効果判定の一助となる。 また, 保湿外用薬 の外用アドヒアランスを高める一つのツールとし ても有用である.

本論文の要旨は第30回日本臨床皮膚科医会総会・臨床 学術大会で報告した。

\section{文 献}

1 ) 石井則久ほか：疥癬診療ガイドライン（第 2 版). 日皮会誌 $117: 1-13,2007$.

2 ) 斎田俊明：疥癄；斎田俊明編, ダーモスコピ
ーのすべて, 南江堂, 東京, 2012, 176-178.

3 ）越後岳士 : 伝染性軟属腫 ; 木村鉄宣他編, 一冊 でわかる皮膚病理, 文光堂, 東京, 2011. 234-235.

4) Shimizu $\mathrm{H}$ et al : White fibrous papulosis of the neck : a new clinicopathologic entity?. J Am Acad Dermatol 20 : 1073-1077, 1989.

5 ) Minagawa A, Koga H, Saida T. : Dermoscopy of white fibrous papulosis of the neck. Arch dermatol $146: 220,2010$.

6 ) 斎田俊明 : white fibrous papulosis of the neck ; 斎田俊明編, ダーモスコピーのすべて, 南江 堂, 東京, 2012, 196.

7 ) 浅井俊弥，木村鉄宣：成人アトピー性皮膚炎 患者にみられた, 頸部の白色小結節. 皮膚病診 療 $34: 61-64,2012$.

8 ) 斎田俊明: 尋常性疮贅; 斎田俊明編, ダーモス コピーのすべて, 南江堂, 東京, 2012, 172-175.

\title{
Utilization of dermoscopy in the observation of findings of conditions other than pigmented skin lesions
}

\author{
Hidetsugu Fukuda and Hideki Mukai \\ Department of Dermatology, Toho University Ohashi Medical Center, Tokyo, Japan
}

The usefulness of dermoscopy, which is used in various clinical settings, has been established in the observation of findings associated with pigmented skin lesions. We herein report the usefulness of this technique in the observation of findings related to conditions other than pigmented skin lesions that are often encountered in daily medical care settings (scabies, molluscum contagiosum, and verruca vulgaris), the treatment course for verruca vulgaris, and symptoms of dryness associated with asteatosis. A diagnosis of scabies can be confirmed when a direct microscopic examination of the crust reveals Sarcoptes scabiei. However, the Guideline for the Diagnosis and Treatment of Scabies states that a diagnosis of scabies can also be made if the presence of $\mathrm{S}$. scabiei is confirmed via dermoscopy. Dermoscopic findings of scabies include gray delta structures that represent the bodies of S. scabiei, the "jet with contrail" signs that represent scabies tunnels, and the "wake" sign. Molluscum contagiosum can often be diagnosed based on macroscopic findings. However, small lesions and white fibrous papulosis of the neck, which are associated with atopic dermatitis, are difficult to diagnose from macroscopic findings in some cases. Dermoscopic findings of molluscum contagiosum include white coloration within the lesion and ring-shaped scales at the lesion center with surrounding crown vessels. In cases of verruca vulgaris, dermoscopy is useful for confirming small lesions and observing the healing course. Furthermore, dermoscopy can be used to confirm keratinization and the presence or absence of dotted vessels that are difficult to identify macroscopically. Patients with asteatosis are prescribed topical moisturizing agents for macroscopically confirmed skin dryness. However, patients in whom dryness cannot be confirmed often discontinue the application of topical agents. In such patients, dermoscopy can be used to confirm the degree of dryness at the time of examination; therefore, this technique is also a useful tool for enhancing adherence to the use of topical moisturizing agents. 